\title{
New records of Vaucheria (Xanthophyceae) from the Lake Baikal region
}

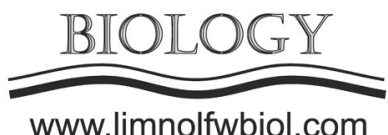

\author{
Vishnyakov V.S. \\ Papanin Institute for Biology of Inland Waters, Russian Academy of Sciences, Borok, 109, 152742, Russia
}

\begin{abstract}
As a result of the field studies (2019-2021), new data were obtained on the Vaucheria, a genus of yellow-green algae, of the Lake Baikal region. After the studying of 30 fertile specimens from new localities, most of them from close vicinities of Lake Baikal, we identified 10 species. The new records improve the species distributional ranges within the Lake Baikal region, which is particularly important for rare species that were previously known from a few localities, e.g. $V$. alaskana, $V$. birostris, $V$. cruciata, $V$. megalaversa, and $V$. prona. Vaucheria uncinata was first recorded from Lake Baikal being occurred in the Pokoinitski bay. A check-list is established for all Vaucheria species, ever discovered in the Lake Baikal region.
\end{abstract}

Keywords: Vaucheria, Siberia, Lake Baikal, new species records, check-list

\section{Introduction}

Vaucheria DC. is among the richest genera of yellow-green algae (Xanthophyceae, Vaucheriaceae) that can be delineated through filamentous coenocytic thalli and oogamous reproduction. The species of Vaucheria can be easily discovered by the naked eye; however, precise species identification requires thorough microscopic observations to detect reproductive structures. The species of Vaucheria occur over a wide range of marine, freshwater, and moist terrestrial habitats worldwide. In the Lake Baikal region (LBR) in Siberia, the studies of Vaucheria have a very brief history. There were only a few studies where these algae are identified at a species rank. Dorogostaisky (1904) first reported 3 species, V. terrestris Lyngb., $V$. racemosa (Vauch.) DC. sensu Götz and V. sessilis (Vauch.) DC., from some tributaries of Lake Baikal and vicinities of Irkutsk. Many years later, Bochka (2000) additionally published new records of $V$. terrestris and $V$. aversa Hass. from small waterbodies of Barguzinsky biosphere reserve, eastern shore of Lake Baikal. All these records lack descriptions or pictures that could confirm identifications, and the voucher specimens have not survived. The author of the present report has studied the genus Vaucheria in LBR. As a result, 15 species were identified, including $V$. megalaversa Vishnyakov, a new species described from the region (Vishnyakov, 2019a; 2019b; 2021; Vishnyakov et al., 2020; for more references see these publications). Although species of

*Corresponding author.

E-mail address: aeonium25@mail.ru (V.S. Vishnyakov)

Received: December 22, 2021; Accepted: December 27, 2021; Available online: December 30, 2021
Vaucheria were revealed among the commonest algae in small lakes, rivers, streams, springs, and wet soils of LBR, none registered in Lake Baikal (cf. Izhboldina, 2007), which is the world's largest freshwater lake. Very little is known yet on Vaucheria species inhabiting tributaries of Lake Baikal and various waterbodies of the nearshore zone.

This report presents new records of Vaucheria from LBR, mostly from close vicinities of Lake Baikal, with a special focus on $V$. uncinata Kütz., a species first recorded from the lake.

\section{Materials and methods}

The specimens originate from various aquatic, semi-terrestrial, and terrestrial habitats. These were collected during the fieldwork in the Irkutsk region and the Republic of Buryatia in 2019-2021. In particular, for the first time, Barguzinski, Eravninski, and Khorinski districts were surveyed. The specimens were studied alive, where possible, or preserved in $95 \%$ alcohol or $4 \%$ formalin in vials. Some parts of abundant specimens were air-dried on cardboard sheets. For light microscopy (LM), several small pieces of each specimen were rinsed with tap water in Petri dishes and then transferred to microscope slides. LM was done using a CNOEC laboratory microscope (Opto-Edu Co. Ltd, Beijing, China) equipped with a digital camera. The voucher specimens were deposited in Vaucheria

(C) Author(s) 2021. This work is distributed under the Creative Commons AttributionNonCommercial 4.0 International License. 
collection, which is currently housed at the Papanin Institute for Biology of Inland Waters, RAS (Borok). A single access number V-n was affixed to each specimen. In total, 35 specimens have been studied, of which 30 specimens consist of fertile filaments and are listed below.

V-584 24.08.2019 Irkutsk region. Slyudyanski district, $123 \mathrm{~km}$ of the Circum-Baikal Railway, $51.776023^{\circ} \mathrm{N}, 104.180452^{\circ} \mathrm{E}$, waterfall on the Kirkirey stream, on wet soil. V-585 24.08.2019 Irkutsk region. Slyudyanski district. $123 \mathrm{~km}$ of the CircumBaikal Railway, tunnel of Kirkirey, $51.776067^{\circ} \mathrm{N}$, 104.180327 ${ }^{\circ} \mathrm{E}$, on wet soil. V-586 24.08.2019 Irkutsk region. Slyudyanski district, the Medlyanka River downstream in Kultuk, $51.725567^{\circ} \mathrm{N}, 103.713176^{\circ} \mathrm{E}$, in water on mosses and Montia fontana, abundantly, 60 ppm, pH 8.5. V-588 28.08.2019 Republic of Buryatia. Pribaikalski district, Goryachinsk, $52.987237^{\circ} \mathrm{N}$, $108.307435^{\circ} \mathrm{E}$, bank of the thermal spring, on wet soil. V-589 29.08.2019 Republic of Buryatia. Barguzinski district, the Maksimikha River downstream, $53.263396^{\circ} \mathrm{N}, 108.741017^{\circ} \mathrm{E}$, rapids near the rock, on mosses, water depth 0-5 cm, abundantly. V-592 04.09.2019 Irkutsk region. Ekhirit-Bulagatski district, karst lake near Gushit, $52.888631^{\circ} \mathrm{N}, 104.975398^{\circ} \mathrm{E}$, on wet soil. V-593 04.09.2019 Irkutsk, flowerbed near "Angara" hotel, on wet soil. V-594 06.09.2019 Irkutsk, $52.291696^{\circ} \mathrm{N}, 104.280019^{\circ} \mathrm{E}$, flowerbed near Beloborodov's monument. V-595 04.09.2019 Irkutsk region. Ekhirit-Bulagatski district, reservoir on the Ordushka River, $52.816101^{\circ} \mathrm{N}, 104.801734^{\circ} \mathrm{E}$, on wet soil in Typha laxmannii community. V-876 04.07.2020 Irkutsk region. Bayandaevski district, ephemeral pond in Bayandai, $53^{\circ} 03^{\prime} 13.4^{\prime \prime} \mathrm{N} 105^{\circ} 30^{\prime} 33.5^{\prime} \mathrm{E}$, in water with Zannichellia and Halerpestes salsuginosa, electrical conductivity $2.4 \mathrm{mS}$, abundantly. V-877 01.08.2020 Irkutsk, bank of the Angara River channel, along Polarnaya Street, $52.354473^{\circ} \mathrm{N}, 104.267525^{\circ} \mathrm{E}$, on wet soil. V-878 26.07.2020 Irkutsk region. Irkutski district, bank of the Krestovka River in Listvyanka, $51^{\circ} 51^{\prime} 21.6^{\prime \prime} \mathrm{N}$ 10451'39.9"E. V-879 12.08.2020 Irkutsk region. Shelekhovski district, right channel of the Olkha River in Olkha, 52 $2^{\circ} 9^{\prime} 27.6^{\prime \prime} \mathrm{N} 104^{\circ} 06^{\prime} 12.6^{\prime \prime E}$, springs. V-881 06.07.2020 Irkutsk region. Olkhonski district, Olkhon Island (Lake Baikal), small lake near Shebetski Bay, $53^{\circ} 08^{\prime} 37.1^{\prime \prime N} 107^{\circ} 07^{\prime} 02.4^{\prime \prime E}$, on depth $30 \mathrm{~cm}$, electrical conductivity $1.5 \mathrm{mS}$. V-883 05.07.2020 Irkutsk region. Olkhonski district, Sakhyurta, wet meadow near Bazarnaya Bay, 5301'05.9”N 10653'04.6”E, ephemeral lake, in water of hoofprints and on wet soil. V-884 04.07.2020 Irkutsk region. Olkhonski district, oxbow of the Anga River near Ust-Anga, 52 46'28.2"N $106^{\circ} 33^{\prime} 24.0^{\prime \prime} \mathrm{E}$, electrical conductivity $446 \mu \mathrm{S}$. V-885 12.07.2020 Republic of Buryatia. Eravninski district, the Domnaya River, 52 $37^{\prime} 10.1^{\prime N} \mathrm{~N} 111^{\circ} 40$ '18.1"E, in water under the bridge, electrical conductivity $258 \mu \mathrm{S}$. V-886 13.07.2020 Republic of Buryatia. Eravninski district, oxbow of the Egita River near Mozhaika, $52^{\circ} 23$ '58.4"N $110^{\circ} 45^{\prime} 58.6$ "E, on wet soil trodden up by cattle. V-887 11.07.2020 Republic of Buryatia. Khorinski district, oxbow in right floodplain of the Uda River, $52^{\circ} 21^{\prime} 14.8 ” \mathrm{~N} 110^{\circ} 23^{\prime} 26.6$ "E, on wet soil trodden up by cattle. V-888 08.08.2020 Republic of Buryatia. Tunkinski district, oxbow of the Irkut River in Tory, $51^{\circ} 47^{\prime} 15.8^{\prime \prime} \mathrm{N} 103^{\circ} 00^{\prime} 03.0^{\prime \prime} \mathrm{E}$, on wet soil trodden up by cattle. V-890 07.08.2020 Republic of Buryatia. Tunkinski district, left branch of the Kyngarga River in Arshan, $51^{\circ} 55^{\prime} 20.9$ 'N $102^{\circ} 25^{\prime} 32.6$ "E, in slow water, electrical conductivity $226 \mu \mathrm{S}, \mathrm{t} 8.2^{\circ} \mathrm{C}$, abundantly. V-904 12.06.2021 Irkutsk region. Irkutski district, Bolshoe Goloustnoe, $52.027611^{\circ} \mathrm{N}, 105.413775^{\circ} \mathrm{E}$, dried ephemeral lake, on wet soil and Carex leaves. V-905 09.06.2021 Irkutsk, floodplain of the Angara River, near "Polyana" park, $52.253184^{\circ} \mathrm{N}, 104.276419^{\circ} \mathrm{E}$, on wet soil. V-906 12.06.2021 Irkutsk region. Irkutski district, right tributary of the Pravaya Ushakovka River, $52.290^{\circ} \mathrm{N}, 104.962^{\circ} \mathrm{E}$, near road, in water, electrical conductivity $72 \mu \mathrm{S}$. V-907 20.06.2021 Irkutsk, Selivanikha, $52.293871^{\circ} \mathrm{N}, 104.234588^{\circ} \mathrm{E}$, oxbow of the Irkut River, electrical conductivity $1085 \mu \mathrm{S}, \mathrm{t} 17.8^{\circ} \mathrm{C}$. V-911 03.08.2021 Irkutsk region. Olkhonski district, Baikal, Zunduk cape, 53.392259 ${ }^{\circ} \mathrm{N}, 107.426535^{\circ} \mathrm{E}$, bank of small lake. V-912 04.08.2021 Irkutsk region. Olkhonski district, Lake Baikal, Pokoiniki cape, bay (Pokoinitski bay), $54.011713^{\circ} \mathrm{N} 108.241753^{\circ} \mathrm{E}$, on 20-30 depth, gravel, electrical conductivity $168 \mu \mathrm{S}$. V-913 08.08.2021 Republic of Buryatia. SeveroBaikalski district, bank of the Ayaya River, $55.456668^{\circ} \mathrm{N}$, $109.915777^{\circ} \mathrm{E}$, on sand. V-914 08.08.2021 Republic of Buryatia. Severo-Baikalski district, bog in the Ayaya River valley, $55.456359^{\circ} \mathrm{N} 109.9231^{\circ} \mathrm{E}$, water pool. V-916 13.08.2021 Irkutsk region. Irkutski district, spring near the Bolshaya Kotinka River downstream, $51.904698^{\circ} \mathrm{N}, 105.073809^{\circ} \mathrm{E}$, electrical conductivity $0.1 \mathrm{mS}, \mathrm{t} 11.5^{\circ} \mathrm{C}$

\section{Results and discussion}

In total, 10 species were identified.

\section{V. alaskana Blum}

Specimens: V-884, 887. Rare species, mostly distributed within the Holarctic. In LBR, the species is known from a few localities in the vicinities of Irkutsk, in rivers of the Eastern Sayan Mountains, and Olkhon Island of Lake Baikal (Vishnyakov, 2019a; 2019b). The species primarily occurs in semi-terrestrial habitats, i.e. riverbank or damp soil, become exposed to the air when the water level recedes. However, specimen $\mathrm{V}-884$ originates from aquatic habitat, being collected near the shore.

\section{V. birostris Simons}

Specimens: V-888. Rare species with a Holarctic distribution. In LBR, the species is known from a few floodplain localities of the Angara, Kuda, Bolshaya Goloustnaya, and Selenga rivers (Vishnyakov, 2019a; 2019b). The species prefers semi-terrestrial habitats.

\section{V. bursata (O.F. Müll.) C. Agardh}

Specimens: V-584, 586, 589, 595, 879, 884, 890, 904, 907, 913, 914, 916. Species with a cosmopolitan distribution, the most common representative of the genus in LBR (Vishnyakov, 2019a; 2019b). This amphibious species can occur in aquatic, semiterrestrial, and terrestrial habitats. 
V. canalicularis (L.) T.A. Chr.

Specimens: 585, 588, 592, 595, 877, 883, 886, 888, 905, 907, 911. Cosmopolitan species, which is one of the commonest in LBR. However, most of the specimens originate from the Irkutsk region, and very rarely from the Republic of Buryatia (Vishnyakov, 2019a; 2019b). The species primarily occurs in aquatic and semi-terrestrial habitats.

V. cruciata (Vauch.) DC.

Specimens: V-905. Cosmopolitan amphibious species, which was rarely recorded from LBR (Vishnyakov, 2019a; 2019b). The species mostly occurs in aquatic and semi-terrestrial habitats of floodplains.

\section{V. frigida (Roth) C. Agardh}

Specimens: V-905, 906, 914. Cosmopolitan amphibious species. In LBR, it is widely distributed in various aquatic, semi-terrestrial, and terrestrial habitats (Vishnyakov, 2019a; 2019b).

\section{V. megalaversa Vishnyakov}

Specimens: V-914, 916. Rare Asian aquatic species. The distribution of $V$. megalaversa appears to be disjunctive between LBR and Ola plateau at the Russian Far East. This was identified previously as a "giant forma of Vaucheria aversa" (Vishnyakov, 2019a; 2019b) and accepted as a distinct species only recently (Vishnyakov, 2021). In LBR, the species was previously known from a few riverine localities surrounding Southern Baikal and Tunka rift valley. One new specimen (V-916) originates from a spring associated with locus typicus, the Bolshaya Kotinka River, a small tributary of Lake Baikal, another one (V-914) comes from a small minerotrophic bog situated nearby northeastern shore of Lake Baikal. The species prefers clean habitats and is currently known from both stagnant and flowing waters.

\section{V. prona T.A. Chr.}

Specimens: V-593, 594. Semi-cosmopolitan species. In LBR, it was previously known from a few localities in Irkutsk and its vicinities, in quarries near Cheremkhovo and in the Selenga River delta
(Vishnyakov, 2019a; 2019b). The species prefers terrestrial or semi-terrestrial habitats, which are frequently disturbed by human activity.

V. racemosa (Vauch.) DC.

Specimens: 589, 876, 878, 881, 883, 885, 888, 914, 916. Semi-cosmopolitan species, one of the commonest in LBR (Vishnyakov, 2019a; 2019b). The species primarily occurs in aquatic habitats, both stagnant and flowing, becoming rare in semi-terrestrial habitats.

\section{V. uncinata Kütz.}

Specimens: V-912. Semi-cosmopolitan amphibious species, which was recorded 5 times from LBR. Previously known localities belong to small tributaries of the Irkutsk reservoir on the Angara, Bolshaya and Burduguz rivers (Vishnyakov, 2019a; 2019b). V. uncinata was first discovered in Lake Baikal in 2021. The locality belongs to Pokoinitski bay, the northwestern shore of the lake, where the species was locally abundant in a sparse community of Persicaria and Carex at the shallowest part (Fig. 1A). The locality is in sharp contrast with an open shore of Lake Baikal, which is exposed to wave activity, deep, and cold, and yet connected directly with it. As is currently known, the coastal zone of Lake Baikal serves as a home for many hydrobionts, both endemics and immigrants from the Holarctic waters, and the latter are commonly restricted to semi-isolated shallowest parts of the lake (Izhboldina, 2007; Timoshkin et al., 2012). In this regard, $V$. uncinata is a species of the Siberian floristic complex that entered the shallow bay. Thorough future investigations of the Lake Baikal coastal zone are needed to determine whether the Vaucheria species is more widely distributed or limited to the known locality.

There are only four species among identified, which can be considered common in LBR: V. bursata, $V$. canalicularis, $V$. frigida, and $V$. racemosa. The rest are sporadically occurred throughout the region.

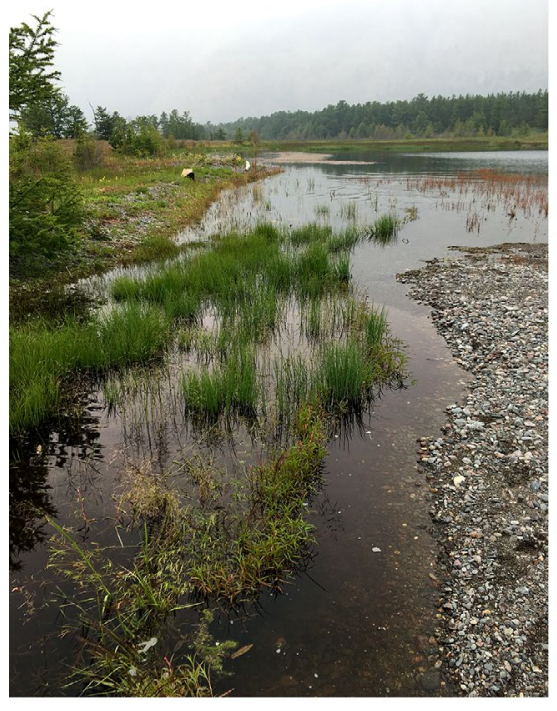

A



B

Fig.1. Locality of Vaucheria uncinata in Lake Baikal (A) and LM micrograph (B) showing fruiting branch bearing stalked antheridium (disintegrated wall is indicated by black arrow) and oogonium without distinctive fertilization pore (white arrow). Scale bar: $100 \mu \mathrm{m}$. 
The most of species show broad geographical ranges that often span more than one continent, and there is a single species, $V$. megalaversa, restricted to local habitats in northeastern Asia. The morphology of all studied species was in good agreement with that of previously studied (Vishnyakov, 2019a; 2021). As a new member of the Lake Baikal algal flora, $V$. uncinata is additionally described here. Filaments are 65-140 $\mu \mathrm{m}$ in diameter. Gametangia born on short lateral gametophores. Each gametophore consists of 1 or 2 pendent oogonia and 1 antheridium (Fig. 1B). Oogonia are ellipsoidal, $130-170 \mu \mathrm{m}$ in diameter. Antheridia are circinate-cylindrical, 32-45 $\mu \mathrm{m}$ in diameter. Asexual reproduction is unknown. An absence of distinctive oogonial fertilization pore allows distinguishing easily $V$. uncinata from all other species in LBR.

Based on the results of our previous studies, we propose here a conspectus of 15 species of the genus Vaucheria in LBR. These belong to 6 sections. I. Section Woroninia (Solms-Laub.) Heer.: V. schleicheri De Wild. (IR). II. Section Corniculatae (Walz) Heer.: V. bursata (O.F. Müll.) C. Agardh (IR, RB). III. Section Tubuligerae (Walz) Heer.: V. fontinalis (L.) T.A. Chr. (IR), V. megalaversa Vishnyakov (IR, RB), V. pseudaversa Vishnyakov (RB). IV. Section Vaucheria: V. birostris Simons (IR, RB), V. canalicularis (L.) T.A. Chr. (IR, RB), V. cruciata (Vauch.) DC. (IR, RB). V. Section Racemosae (Walz) Entwisle: V. alaskana Blum (IR, RB), V. frigida (Roth) C. Agardh (IR, RB), V. nuoljae (Skuja) Vishnyakov (IR), V. prona T.A. Chr. (IR, RB), V. racemosa (Vauch.) DC. (IR, RB), V. taylorii Blum (RB). VI. Section Heeringia Blum: V. uncinata Kütz. (IR). Abbreviations: IR - Irkutsk Region, RB - Republic of Buryatia.

\section{Conclusions}

The present report improves significantly the distributional ranges of 10 previously reported species within the Lake Baikal region, which is particularly important for rare species that were previously known from a few localities. One such species is $V$. uncinata, which was first discovered in Lake Baikal.

\section{Acknowledgments}

The study was performed as a part of the state assignment of the Russian Federation to IBIW RAS, no. 121051100099-5. Thanks to the crews of "Titov" and "Professor Kozhov" research vessels, E.A. Volkova, E.V. Mincheva, T.E. Peretolchina (Limnological Institute of SB RAS, Irkutsk) for comprehensive assistance in field studies.

\section{Conflict of interests}

The author declares no conflict of interests

\section{References}

Bochka A.B. 2000. Vodorosli [Algae]. In: Flora i fauna vodoemov i vodotokov Barguzinskogo zapovednika. Flora i fauna zapovednikov. Annotirovannye spiski vidov. Vyp. 91 [Flora and fauna of waterbodies and streams of Barguzin Reserve. Flora and fauna of reserves. Annotated lists of species. Vol. 91]. Moscow, pp. 8-123. (in Russian)

Dorogostaisky V. 1904. Materiaux pour servir a l'algologie du lac Baikal et de son basin. Bulletin de la Société Impériale des Naturalistes de Moscou. Nouvelle Série [Bulletin of the Imperial Moscow Society of Naturalists. New Series] 18(1): 229-265. (in French)

Izhboldina L.A. 2007. Atlas i opredelitel' vodorosley bentosa i perifitona ozera Baikal (meyo- i makrofity) s kratkimi ocherkami po ikh ekologii [Guide and key to benthonic and periphyton algae of Lake Baikal (meio- and macrophytes) with short notes of their ecology]. Novosibirsk: Nauka-Center. (in Russian)

Timoshkin O.A., Suturin A.N., Bondarenko N.A. et al. 2012. Introduction into biology of the coastal zone of Lake Baikal. 1. Splash zone: first results of interdisciplinary investigations and its role for the lake ecosystem monitoring. Izvestiya Irkutskogo Gosudarstvennogo Universiteta [The Bulletin of Irkutsk State University] 5(3): 33-46. (in Russian)

Vishnyakov V.S. 2019a. Representatives of genera Botrydium Wallroth and Vaucheria De Candolle (Xanthophyceae) in the South of Baikal Region (Russia). International Journal on Algae 21(1): 25-42. DOI: 10.1615/ InterJAlgae.v21.i1.20

Vishnyakov V.S. 2019b. The localities of Vaucheria (Xanthophyceae) in Irkutsk Region and Republic of Buryatia. Trudy Instituta Biologii Vnutrennikh Vod im. Papanina [Transactions of Papanin Institute for Biology of Inland Waters] 85(88): 44-58. (in Russian)

Vishnyakov V.S. 2021. Revision of Vaucheria sect. Tubuligerae (Xanthophyceae) in Russia. Botanicheskii Zhurnal [Botanical Journal] 106(7): 703-723. (in Russian)

Vishnyakov V.S., Romanov R.E., Chemeris E.V. et al. 2020. New records of Vaucheria (Ochrophyta, Xanthophyceae) in Russia. Novosti Sistematiki Nizshikh Rastenii [Non-vascular Plants Taxonomy News] 54(1): 7-41. (in Russian) 